\title{
'N KRITIESE EVALUERING VAN DIE BELEID TEN OPSIGTE VAN PROSTITUSIE IN SUID-AFRIKA EN ALTERNATIEWE VIR DIE TOEKOMS
}

\author{
Rinda Botha
}

BJuris LLB LLM LLD

Senior dosent

Departement Straf- en Geneeskundige Reg

Universiteit van die Vrystaat

Hennie Oosthuizen

BJuris LLB LLD LLD

Professor en Hoof: Departement Straf-

en Geneeskundige Reg

Universiteit van die Vrystaat

\section{SUMMARY}

This article critically investigates the prohibitionist approach that is currently followed with regard to prostitution in South Africa. The problems of violence, absence of control over the spreading of HIV as well as sexworkers' lack of labour rights specifically enjoy attention. The alternative approaches of abolition, regulation and the labour approach (followed by some other countries) are investigated with the purpose of new proposals concerning South Africa's future in this respect. Authors of this article are of a view that an approach, combining a regulating and a labourapproach, might lead the way to an improvement in the treatment of prostitution, although it might pose a huge challenge to South Africa as a developing country.

Prostitusie, kortliks beskryf as seks teen vergoeding, ${ }^{1}$ het sterk teenkanting en verskeie opinies oor die jare heen uitgelok en is vandag steeds ' $n$ onderwerp waaroor regerings kopkrap en mense se sienings verskil. ${ }^{2}$

Snyman Strafreg (2008) 383.

Legalbrief TODAY "Legislation: Calls to legalise prostitution before World Cup"

http://www.legalbrief.co.za (nageslaan 31 Januarie 2008):

"it is one of the things that would make the World Cup a success because we hear of many rapes, because people don't have access to women. If sex work were legalized, 
Die keuse van 'n benadering ten opsigte van prostitusie in ' $n$ land is van groot belang vanweë die rimpeleffek wat dit op ander terreine van die samelewing en die reg as sodanig kan toon.

Hierdie artikel bied 'n kort oorsig van die hantering van prostitusie in SuidAfrika in die verlede asook die grondwetlike toetse waaraan dit reeds onderwerp is. Die benadering ten opsigte van voorkoming, wat tans in SuidAfrika gevolg word, word krities ondersoek en probleemareas daaraan verbonde, geïdentifiseer. Geweld teenoor sekswerkers, die gebrek aan kontrole oor die verspreiding van MIV/VIGS asook die afwesigheid van arbeidsregte in die uitvoer van die sekswerker se beroep, geniet veral aandag.

In die soeke na oplossings vir die probleme wat tans ondervind word, word alternatiewe benaderings (soos in sommige ander lande gevolg), naamlik die afskaffingsbenadering, die reguleringsbenadering asook die arbeids-benadering ondersoek en 'n nuwe benadering word voorgestel met die hoop op 'n beter toekoms vir Suid-Afrika in dié verband.

\section{HISTORIESE OORSIG}

Die destydse regering aan die Kaap het prostitusie in 1868 begin reguleer deur die toepassing van die Wet op die Voorkoming van Aansteeklike Siektes, ${ }^{3}$ wat sekswerkers verplig het om minstens twee keer per maand ondersoeke vir geslagsiektes te ondergaan. ${ }^{4}$ In 1882 het die Wet op Polisieoortredings ${ }^{5}$ voorsiening gemaak vir 'n boete van hoogstens twee pond of gevangenisstraf van hoogstens 30 dae indien sekswerkers vir doeleindes van dronkenskap en prostitusie in openbare plekke sou verskyn. ${ }^{6}$ Kinderprostitusie is eers in 1893 ingevolge die Wysigingswet op die Strafreg ${ }^{7}$ verbied.

In Transvaal het wetgewing wat prostitusie en bordele verbied het tussen 1897 en 1899 ontstaan. ${ }^{8}$ Dit was hoofsaaklik 'n gevolg van die vloedgolf sekswerkers wat die goud- en diamantstormloop na Transvaal vergesel het. ${ }^{9}$ $\mathrm{Na}$ aanleiding van hierdie wetgewing het sekwerkers Transvaal verlaat en na die Kaap, Vrystaat asook na Natal gegaan, waar soortgelyke wetgewing

people would not do things in the dark. That would bring us taxes and would improve the lives of those who are not working" (George Lekgetho).

"You cannot attach a price to the deepest union between a man and a woman and link it to our tax base" (Sydney Opperman).

Wet 25 van 1868

Art $\mathrm{V}$ van Wet 25 van 1868.

Wet 27 van 1882

Art 5(29) van Wet 27 van 1882.

Wet 25 van 1893

8 Art 2 en 6 van Wet 2 van 1897; Art 2 en 3 van Wet 23 van 1898; en Art 2 en 4 van Wet 11 van 1899 .

9 De Bruyn " $n$ Bespreking van die Vraagstuk of Prostitusie in Suid-Africa Gedekriminaliseer behoort te word" 1996 9(2) Acta Criminologica 41. 
later deurgevoer is. Hierdie koloniale reëlings het voortgeduur tot 1957, toe dit herroep en vervang is deur die destydse Ontugwet. ${ }^{10}$

Eers in 1988 is die Ontugwet ${ }^{11}$ gewysig om sodoende ontug of ' $n$ onsedelike daad met ' $n$ ander teen vergoeding as misdaad te verklaar.

Hierna en tot voor die inwerkingtreding van die Wysigingswet op die Strafreg $^{13}$ op 16 Desember 2007 (wat later bespreking sal geniet) is prostitusie ingevolge artikel 20(1)(aA) van die Wet op Seksuele Misdrywe 23 van 1957 as misdaad vervolg. Verpligte tronkstraf van tot drie jaar en 'n boete van tot R6 000 was en is steeds moontlik vir hierdie oortreding. ${ }^{14}$

\section{DIE GRONDWETLIKHEID VAN PROSTITUSIE AS MISDRYF}

Die vraag oor die grondwetlikheid van die voortbestaan van prostitusie as misdryf in Suid-Afrika het in Ellen Jordan en Twee Andere $v$ Die Staat, ${ }^{15}$ aandag geniet. In 'n beslissing van $\operatorname{ses}^{16}$ regters teen vyf ${ }^{17}$ is daar besluit dat prostitusie as misdryf sal voortbestaan. ${ }^{18}$

In hierdie saak is geargumenteer dat die voortbestaan van prostitusie as misdryf onder andere die reg tot gelykheid, ${ }^{19}$ menswaardigheid, ${ }^{20}$ vryheid en sekuriteit van die persoon, ${ }^{21}$ privaatheid ${ }^{22}$ en ekonomiese verkeer, ${ }^{23}$ soos in die Interim Grondwet ${ }^{24}$ vervat, skend.

\footnotetext{
Wet 23 van 1957; en De Bruyn 1996 9(2) Acta Criminologica 41.

Wet 23 van 1957.

Ingevolge die Ontugwysigingswet 2 van 1988.

Wet 32 van 2007.

Art 22(a) van Wet 23 van 1957.

20022 SACR 499 (CC).

16 Die meerderheidsuitspraak is gelewer deur regter Ngcobo. Hoofregter Chaskalson en regters Kriegler, Du Plessis, Madala en Skweyiya het met hom saamgestem.

17 Die minderheidsuitspraak is gelewer deur regters Sachs en O'Regan. Regters Langa, Ackermann en Goldstone het met hulle saamgestem.

18 Ellen Jordan en Twee Andere $v$ Die Staat supra 513 par 33.

19 Art 8(1): Elke persoon het die reg op gelykheid voor die reg en op gelyke beskerming deur die Reg.

Art 8(2): Daar mag teen niemand onbillik gediskrimineer word nie, hetsy direk of indirek, en, sonder om afbreuk te doen aan die algemeenheid van hierdie bepaling, in die besonder op een of meer van die volgende gronde: ras, geslagtelikheid, geslag, etniese of sosiale herkoms, kleur, seksuele georiënteerdheid, ouderdom, gestremdheid, godsdiens, gewete, geloof, kultuur of taal.

20 Art 10 bepaal dat elke persoon die reg het op respek vir en beskerming van sy of haar waardigheid.

21 Art 11 bepaal dat elke persoon die reg het op vryheid en die sekuriteit van sy of haar persoon, waarby inbegrepe is die reg om nie sonder verhoor aangehou te word nie.

22 Art 13 bepaal dat elke persoon die reg het op sy of haar persoonlike privaatheid, waarby inbegrepe is die reg om nie aan visentering van sy of haar persoon, woning of eiendom, die beslaglegging op private besittings of die skending van private kommunikasie onderwerp te word nie.

23 Art 26(1): Elke persoon het die reg om vrylik aan die ekonomiese verkeer deel te neem en om op enige plek in die nasionale grondgebied ' $n$ lewensbestaan te voer.
} 
Volgens regter Ngcobo, ${ }^{25}$ verantwoordelik vir die meerderheidsuitspraak, was die sentrale vraag voor die hof egter of artikel 20(1)(aA) van die Wet op Seksuele Misdrywe ${ }^{26}$ onbillik teen vroue (wat ongeveer $95 \%$ van alle sekswerkers vorm) ${ }^{27}$ diskrimineer. Die bespreking wat volg, word derhalwe tot hierdie vraagstuk beperk.

Artikel 20(1)(aA) lees soos volg:

"20. Persone wat van opbrengs van prostitusie leef of wat onsedelike dade pleeg of by die pleeg daarvan help.

(1) lemand wat -

(aA) ontug of 'n onsedelike daad met 'n ander persoon teen vergoeding pleeg,

is aan 'n misdryf skuldig."

Regter Ngcobo was van mening dat alhoewel daar in terme van hierdie artikel 'n onderskeid getref word tussen handelaar (die sekswerker wat haar dienste te koop aanbied) en verbruiker (die kliënt wat vir die dienste betaal), dit gesien moet word teen die agtergrond dat die verbruiker (kliënt) ook skuldig bevind kan word aan die oortreding van hierdie artikel en strafbaar is met dieselfde straf as die sekswerker. ${ }^{28}$

Die kliënt se strafregtelike aanspreeklikheid spruit uit artikel 18(2) van die Wet op Oproerige Byeenkomste 17 van $1956 .^{29}$

Artikel 18(2) lui soos volg:

"18. Poging, sameswering en aansporing van iemand anders om 'n misdryf te pleeg. -

(1) lemand wat -

(a) met 'n ander persoon saamsweer om by die pleeg van 'n misdryf, hetsy ingevolge die gemene reg of ingevolge 'n statuut of ' $n$ statutêre regulasie, behulpsaam te wees of om dit te bewerkstellig of te pleeg; of

(b) 'n ander persoon uitlok, aanstig, beveel of verkry om so 'n misdryf te pleeg,

is aan 'n misdryf skuldig en by skuldigbevinding strafbaar met die straf waarmee 'n persoon wat weens die werklike pleging van daardie misdryf skuldig bevind is, gestraf kan word."

Art 26(2) Subartikel (1) belet nie maatreëls wat daarvoor ontwerp is om die beskerming of die verbetering van die lewenskwaliteit, ekonomiese groei, mensontwikkeling, sosiale geregtigheid, basiese diensvoorwaardes, billike arbeidspraktyke of gelyke geleenthede vir almal te bevorder nie, mits sodanige maatreëls regverdigbaar is in 'n oop en demokratiese samelewing en gebaseer op vryheid en gelykheid.

200 van 1993

25 Ellen Jordan en Twee Andere v Die Staat supra 507 par 8.

2623 van 1957.

27 Women's Media Watch, South Africa and Sex Worker Education and Advocacy Taskforce "Sex Sells': Monitoring reporting on the sex industry through a gender lens" http://www.samgi.org.za/Publications/booklets/monitoringSexIndustry.pdf (nageslaan op 7 September 2006). "The majority of sex workers are female (approximately 95\%) but there are also male and transgendered sex workers."

28 Ellen Jordan en Twee Andere v Die Staat supra 508 par 11.

29 Ibid. 
Uit bogenoemde is dit duidelik dat die kliënt strafregtelik aanspreeklik gehou kan word en dieselfde straf as die sekswerker opgelê kan word op grond daarvan dat die kliënt die misdaad deur die sekswerker gepleeg, bevorder het.

Regters Sachs en O'Regan, in hul minderheidsuitspraak, was egter van mening dat indien kliënte in die lig van bogenoemde vervolg sou word, artikel 20(1)(aA) steeds indirek teen vroue (as sekswerkers) diskrimineer. Volgens artikel 20(1)(aA) word die sekswerker as die prinsipaal (hoofoortreder) gebrandmerk, terwyl die kliënt slegs as 'n medepligtige ${ }^{30}$ afgemaak word. Hoewel die verskil 'n klein impak in formele regsterme mag hê, mag dit 'n groter effek toon op die houding teenoor en algemene siening van sekswerkers in die oë van die gemeenskap. Die primêre misdryf word dus gesien as die aanbied van seksuele dienste en nie die aankoop daarvan nie. $^{31}$ Hierdie standpunt van die minderheidsuitspraak word derhalwe ondersteun.

Regters Sachs en O'Regan se aanbeveling was dat artikel 20(1)(Aa) nie net van die wetboek moet verdwyn nie, maar vir 'n periode van 30 maande opgeskort moet word om sodoende vir die staat 'n geleentheid te bied om die hantering van prostitusie (met inbegrip van die reg tot gelykheid) te heroorweeg.

Regter $\mathrm{Ngcobo}^{33}$ en die vyf regters wat sy sienswyse gesteun het, het egter volhard dat artikel 20(1)(aA) nie diskriminerend en dus nie ongrondwetlik is nie. Regter Ngcobo het dit verder duidelik gemaak dat dit slegs die taak van die howe is om die reg toe te pas en dit nie te skep nie. ${ }^{34}$ Volgens hom vorm die wysiging van die bestaande wetgewing met betrekking tot prostitusie tot meer effektiewe maatreëls, deel van die werksaamhede van die Wetgewer. ${ }^{35}$

Die meerderheidsbeslissing het dus die grondwetlikheid van die voortbestaan van prostitusie as misdryf in Suid-Afrika verseker en terselfdertyd die weg gebaan vir 'n omvattende ondersoek rondom die doeltreffendheid van nuwe maatreëls in hierdie verband. ${ }^{36}$

30 Snyman 273. "A person is guilty of a crime as an accomplice if, although he does not satisfy all the requirements for liability contained in the definition of the crime and although the conduct required for a conviction is not imputed to him by virtue of the principles relating to common purpose, he unlawfully and intentionally engages in conduct whereby he furthers the commission of a crime by somebody else."

Ellen Jordan en Twee Andere v Die Staat supra 524 par 63.

32 Ellen Jordan en Twee Andere v Die Staat supra 549 par 129; en 548 par 126.

Ellen Jordan en Twee Andere v Die Staat supra 512 par 31.

34 Ellen Jordan en Twee Andere $v$ Die Staat supra 512 par 30.

35 Ibid.

36 South African Law Reform Commission "Sexual Offences: Adult Prostitution Summary" Issue Paper 19, Project 107 (2002-09-03). 


\section{DIE WYSIGINGSWET OP DIE STRAFREG (SEKSUELE MISDRYWE EN VERWANTE AANGELEENTHEDE) 32 VAN 2007}

Ondanks druk uit verskeie oorde dat prostitusie gedekriminaliseer moet word, is prostitusie onlangs ingevolge die Wysigingswet op die Strafreg (Seksuele Misdrywe en Verwante Aangeleenthede) $^{37}$ opnuut in Suid-Afrika as misdaad bevestig. ${ }^{38}$

Artikel 20 van Wet 23 van 1957 is ingevolge die Wysigingswet ${ }^{39}$ gewysig deur die invoeging van 'n nuwe subartikel $(1 \mathrm{~A})$ wat die vorige subartikels $20(1)(a A)$ en (b) vervang. Subartikel (1A) bepaal steeds dat ontug of ' $n$ onsedelike daad met ' $n$ ander persoon teen vergoeding of die pleeg van ' $n$ onsedelike daad met ' $n$ ander in die openbaar deur persone ouer as 18, 'n misdaad is. Die enigste wysiging wat in effek ingetree het, is dus die ouderdomsbepaling wat bygevoeg is. Dit blyk dus of dit die doel van die wysiging was om sekswerkers van 18 en jonger van strafregtelike vervolging te vrywaar.

Hoe dit ook al sy, dit was dus die keuse van die parlement om die verbod op prostitusie te behou totdat die Suid-Afrikaanse Regskommissie sy omvattende ondersoek na die posisie van sekswerkers afgehandel het. ${ }^{40}$ Alhoewel daar bevestig is dat die Suid-Afrikaanse Regskommissie omvangryke werk oor prostitusie doen, is dit steeds onbekend wanneer hulle voorstelle voorgelê sal word en wat die presiese aard daarvan sal wees. ${ }^{41}$

Intussen maak artikel 11 van die Wysigingswet ${ }^{42}$ nou ook spesifiek voorsiening vir die vervolging van sekswerkers se kliënte. Dit is waarskynlik 'n gevolg van die Grondwethof se minderheidsbeslissing in die saak Ellen Jordan en Twee Andere $v$ Die Staat ${ }^{43}$ wat daarop gedui het dat die vervolging van kliënte in terme van artikel $20(1)(\mathrm{aA})$ as medepligtiges op indirekte diskriminasie op grond van geslag neerkom. ${ }^{44}$

Artikel 11 van Wet 32 van 2007 lees soos volg:

"lemand ('A') wat wederregtelik en opsetlik die dienste van 'n persoon 18 jaar of ouer ('B'), vir finansiële of ander beloning, guns of vergoeding aan $B$ of ' $n$ derde persoon ('C'), verkry -

(a) met die doel om 'n seksuele handeling met B te pleeg, ongeag of die seksuele handeling gepleeg word al dan nie; of

(b) deur 'n seksuele handeling met B te pleeg,

is skuldig aan die misdryf van verkryging van die seksuele dienste van ' $n$ persoon 18 jaar of ouer."

\footnotetext{
Wet 32 van 2007.

"Nuwe Wet Teiken Kliënte van Prostitute" 2007-12-11 Die Burger.

32 van 2007.

"Nuwe Wet Teiken Kliënte van Prostitute" 2007-12-11 Die Burger.

"Paying for Sex is Now a Crime" 2007-12-15 Saturday Weekend Argus.

Wet 32 van 2007

Supra.

Ellen Jordan en Twee Andere v Die Staat supra 524 par 63.
} 
Kliënte kan dus nou as 'n prinsipaal (hoofoortreder) in terme van artikel 11 van Wet 32 van 2007 vervolg word. Regters Sachs en O'Regan het egter in hul minderheidsuitspraak daarop gewys dat daar nie een saak van vervolging van ' $\mathrm{n}$ verbruiker (kliënt) van prostitusie voor die hof se aandag in Ellen Jordan en Twee Andere ${ }^{45}$ gebring is nie sedert die bekendstelling van artikel $20(1)(\mathrm{aA})$ in $1988 .{ }^{46}$ Of vervolging, wat wel in terme van artikel $20(1)(a A)$ ' $n$ moontlikheid was, maar nooit plaasgevind het nie, nou inderdaad sal geskied, bly dus 'n ope vraag.

\section{ALTERNATIEWE OORWEGINGS}

In die oorweging van 'n nuwe benadering ten opsigte van prostitusie in SuidAfrika, kan 'n oorsig van die verskeie benaderings soos deur ander lande gevolg, as belangrike rigtingaanwyser dien. 'n Bondige samevatting van die vier vernaamste benaderings wat oor lande heen gevolg word, kan soos volg uiteengesit word:

\section{Die voorkomingsbenadering}

Volgens die voorkomingsbenadering word prostitusie as kriminele gedrag, waarvoor sekswerkers gestraf of gebiedend hervorm moet word, beskou. Alle aktiwiteite verbandhoudend met prostitusie en alle partye daarby betrokke se optrede word gekriminaliseer. ${ }^{47}$

Omrede Suid-Afrika tans van hierdie benadering gebruik maak om prostitusie te bekamp, geniet die probleme voortspruitend uit hierdie benadering later afsonderlike aandag.

\section{Die afskaffingsbenadering}

Volgens die afskaffingsbenadering word sekswerkers nie as misdadigers nie, maar as slagoffers beskou. Prostitusie word dus as 'n vorm van seksuele geweld beskou. Die onderliggende gedagte van hierdie benadering is daarin geleë dat prostitusie slegs voortbestaan omrede bordeeleienaars, koppelaars en handelaars, vrouens tot prostitusie lok om wins uit sekswerkers se verdienste te maak. Voorstanders van hierdie benadering glo dat die afskaffing van prostitusie en die beskerming van vroue bereik kan word deur middel van die bestrawwing van hierdie "derde partye". Hierdie derde partye is dan enige persone wat 'n ander probeer oortuig om seksuele dienste te lewer, wins daaruit probeer maak of prostitusie probeer organiseer. $^{48}$

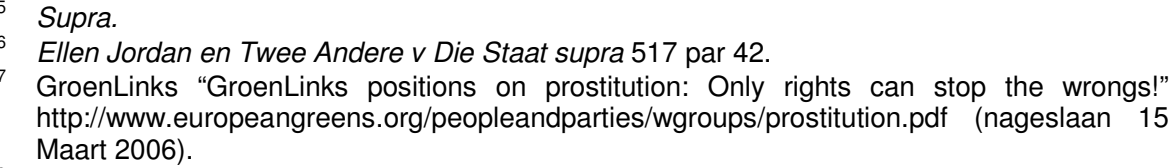


Alhoewel seks teen vergoeding nie verbode vir die sekswerker is nie, is dit byna onmoontlik om diens as sekswerker te verrig omrede enige werk ' $n$ sekere mate van organisasie, soos die huur van 'n werkplek, die ontvangs van kliënte en samewerking van kollegas, vereis. Die reg self ontneem dus die sekswerker van noodsaaklike geriewe wat haar inkomste verseker. ${ }^{49} \mathrm{Die}$ rede daarvoor is dat derde partye se betrokkenheid by prostitusie, steeds onwettig is. Die impak van hierdie benadering tot prostitusie is 'n kombinasie van isolasie, stigmatisering en die sosiale verwerping van sekswerkers. ${ }^{50}$

'n Nuwe verskyningsvorm van hierdie benadering is om die kliënt se gedrag te kriminaliseer. ${ }^{51}$ Dit lei tot die vermindering van uitlokking op straat en die gebruik van minder sigbare metodes om kliënte te ontmoet. Sekswerk word derhalwe ondergronds gedryf.

Met die fokus op die nadelige gevolge van prostitusie op vroue, hou voorstanders van hierdie benadering egter vol dat die beleid van bestrawwing van almal betrokke in prostitusie, behalwe die sekswerker self, 'n moet is. ${ }^{52}$

\section{Die reguleringsbenadering}

Volgens hierdie benadering word prostitusie as 'n onvoorkombare en selfs noodsaaklike euwel beskou. ${ }^{53}$ Die bestaan van prostitusie word min of meer aanvaar, maar terselftertyd as 'n gevaar vir die samelewing se gesondheid en orde beskou. Om die samelewing dus van die gevare verbonde aan hierdie noodsaaklike euwel te beskerm, word prostitusie gereguleer. ${ }^{54}$ Alhoewel sekswerkers se werk nie onwettig is nie, geniet hulle geen regte as werknemers nie en neem die staat ook nie verantwoordelikheid vir hulle werksomstandighede nie. ${ }^{55}$

Regulering geskied gewoonlik deur middel van verskillende vorme van verpligte registrasie en ander metodes van staatsbeheer. Voorbeelde van regulering sluit in die verpligte mediese ondersoeke van sekswerkers om openbare gesondheid te beskerm, 'n verbod op dienslewering buite die grense van sekere areas of plekke, 'n verbod op dronkenskap, asook

49 Ibid.

50 lbid.

51 Kyk ook Meyer "Decriminalizing Prostitution: Liberation or Dehumanization?" 1993-1994(1) Cardozo Women's LJ 114 wat reeds in 1993 hierop gewys het: "Some suggest criminalizing only the purchase of sex - jailing only the 'johns'. What fun to hear the outcry from the Reagan-Bush judiciary over this violation of equal protection!"

52 Inglis "Expanding International and National Protection Against Trafficking for Forced Labor Using a Human Rights Framework" 20017 Buffalo Human Rights LR 86.

53 GroenLinks "GroenLinks Positions on Prostitution: Only Rights can Stop the Wrongs!" http://www.europeangreens.org/peopleandparties/wgroups/prostitution.pdf (nageslaan op 2006 03-15).

54 Kyk ook Meyer 1993-1994(1) Cardozo Women's Law J 114: "Regulation generally aims at preventing the spread of sexually transmitted diseases (STD's) - venereal disease and more recently AIDS - as well as at imposing what might be called time, place and manner restrictions on the practice or advertisement of prostitution."

55 GroenLinks http://www.europeangreens.org/peopleandparties/wgroups/prostitution.pdf (nageslaan op 15 Maart 2006). 
regulasies rakende die nasionaliteit en residensiële status van die vroue betrokke in die seksbedryf (gewoonlik gepaardgaande met strawwe vir vroue wat nie aan die regulasies voldoen nie).

\section{Die arbeidsbenadering}

Die arbeidsbenadering word deur sekswerkers voorgestaan. ${ }^{57}$ Hiervolgens veg sekswerkers teen hulle uitsluiting van gewone regte wat die samelewing aan andere bied. Sekswerkers vra vir die erkenning van sekswerk as beroep en die dekriminalisering van sekssakeondernemings om sodoende die regulering van die seksindustrie deur middel van siviele en arbeidsreg eerder as die strafreg te bereik. ${ }^{58}$

\section{KERNPROBLEME TEN OPSIGTE VAN DIE VOOR- KOMINGSBENADERING}

Soos reeds hierbo aangedui, volg Suid-Afrika tans die voorkomingsbenadering en poog om prostitusie met strafmaatreëls te beveg. Alle aktiwiteite verbandhoudend met prostitusie en alle partye daarby betrokke se bedrywighede word gekriminaliseer. ${ }^{59}$

Drie kernprobleme voortspruitend uit hierdie benadering naamlik, die voorkoms van geweld in die uitoefening van die sekswerker se beroep, die gebrek aan beheer oor die verspreiding van MIV asook die afwesigheid van sekswerkers se toegang tot arbeidsregte, geniet nou afsonderlike aandag:

\section{Die hoë voorkoms van geweld teenoor sekswerkers}

Sekswerkers staan tans onbeskermd teen geweld in die uitoefening van hul onwettige beroep.

'n Studie geloods oor 'n tydperk van 7 jaar, waaraan 854 sekswerkers van verskeie lande, insluitende Suid-Afrika, deelgeneem het, het daarop gedui dat tussen $70 \%$ en $95 \%$ van die sekswerkers fisiese aanranding in die seksbedryf ondervind het, tussen $60 \%$ en $75 \%$ van die sekswerkers al

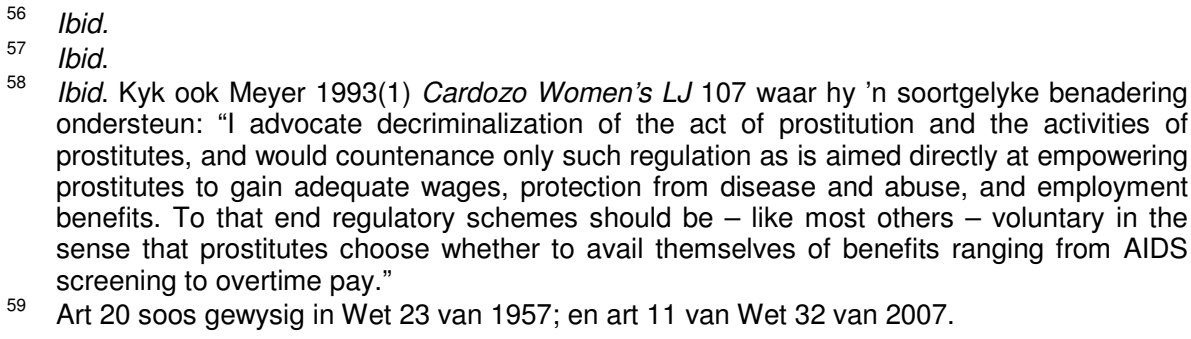

Ibid. Kyk ook Meyer 1993(1) Cardozo Women's LJ 107 waar hy 'n soortgelyke benadering ondersteun: "I advocate decriminalization of the act of prostitution and the activities of prostitutes, and would countenance only such regulation as is aimed directly at empowering prostitutes to gain adequate wages, protection from disease and abuse, and employment benefits. To that end regulatory schemes should be - like most others - voluntary in the sense that prostitutes choose whether to avail themselves of benefits ranging from AIDS screening to overtime pay."

59 Art 20 soos gewysig in Wet 23 van 1957; en art 11 van Wet 32 van 2007. 
verkrag is en al die sekswerkers seksuele teistering in die uitoefening van hul beroep ervaar het. ${ }^{60}$

Daar kan verwag word dat misdade teen sekswerkers gepleeg nie geredelik aangemeld sal word nie vanweë die misdadigheid van hulle beroep en moontlike vervolging in dié verband. Hulle mag ook verdere blootstelling en vernedering van die polisiemag vrees. ${ }^{61}$ 'n Opname in Bangladesh ten opsigte van 540 vroulike sekswerkers het getoon dat $49 \%$ van die 540 sekswerkers wat aan die studie deelgeneem het in daardie jaar deur die polisie verkrag is en $59 \%$ deur polisiebeamptes aangerand is. ${ }^{62}$

Behalwe dan vir die moontlike geweld deur kliënte en die polisie, word sekswerkers ook blootgestel aan misbruik deur hul koppelaars ${ }^{63}$ indien hulle in 'n koppelaar-verhouding sou staan. Volgens Norton-Hawk ${ }^{64}$ se navorsing onder sekswerkers in die Verenigde State van Amerika (wat hoofsaaklik ook die voorkomingsbenadering volg), ${ }^{65}$ is misbruik deur die koppelaar algemeen, met $53 \%$ van haar studiegroep sekswerkers wat dit as 'n groot probleem beskou het. Die sekswerkers het gereelde aanranding met die opset om ernstig te beseer en verkragting deur koppelaars gerapporteer.

Die onwettigheid van sekswerkers se beroep belemmer dus hulle toegang tot die gereg en stel hulle bloot aan die toediening van geweld uit verskeie oorde.

60 Ellen Jordan en Twee Andere $v$ die Staat supra: 'n Verklaring deur dr Melissa Farley par 137-10: Bylae "AVE3". Kyk ook Willis en Barry "Child Prostitution: Global Health Burden, Research Needs, and Interventions" 2002 The Lancet 359(9315):1417 waarvolgens 'n studie van 475 sekswerkers van vyf verskillende lande die volgende resultate opgelewer het:

- $73 \%$ het fisiese aanranding in die uitvoer van hul werksaamhede ervaar

- $62 \%$ is verkrag vanaf hul toetrede tot die bedryf.

Kyk verder Valera "Violence and post-traumatic stress disorder in a sample of inner city street prostitutes" 2000 American Journal of Health Studies 16(3):149 se resultate van 'n studie onder 100 sekswerkers in Washington:

- $60 \%$ van die teikengroep het geweld tydens hul deelname aan prostitusie ondervind.

- $44 \%$ is verkrag.

61 Kyk ook "Caught between the law and brute force of men" 2001-08-19 Sunday Independent wat wys op 'n geval waar 'n ses-en-dertigjarige Bernadette met 'n geweer in die mond deur teenwoordige kliënte verkrag is, terwyl visdraad om haar nek en 'n plastieksak om haar kop gebind was. Dankbaar dat sy nog lewe en met die motorregistrasienommer van haar aanvallers in haar besit, het sy na die polisie gegaan om die saak te gaan aangee. Die polisiebeampte aan diens se opmerking was soos volg:

"Not to bother, we will never find the men. Anyway, you were asking for it in the first place."

Kyk verder Watts en Zimmerman "Violence Against Women: Global Scope and Magnitude" 2002(359) The Lancet 1233: "girls or women who have been sexually assaulted or raped are frequently said to have 'asked for it' by the way they were dressed or behaved - even when the victim is a child."

62 Watts en Zimmerman 2002 (359) The Lancet 1238.

63 Snyman Strafreg (2006) 374: "Koppelary is, algemeen gesproke, 'n handeling waardeur iemand 'n ander (gewoonlik 'n vrou) verkry, hetsy deur bedrog, geslepenheid, dwang of oorreding, om 'n prostituut te word."

64 "Incarcerating Female Street Prostitutes" 2001(22) Deviant Behavior: An Inter-disciplinary J 412.

65 Meyer 1993-1994(1) Cardozo Women's LJ 106. 
Brents en Hausbeck ${ }^{66}$ se navorsing in bordele van Nevada waar

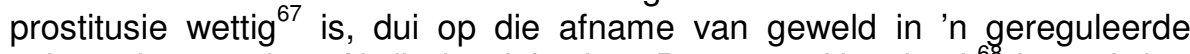
sekswerkomgewing. Al die bordele deur Brents en Hausbeck ${ }^{68}$ besoek het sogenaamde paniekknoppies in elke sekswerker se kamer gehad wat as groot bron van sekuriteit vir die sekswerkers gedien het. Sekswerkers was egter van mening dat die grootste beskermingsmeganisme daarin geleë is dat hul dienste in 'n omgewing gelewer word waar die hulp van andere slegs deur middel van 'n deur geskei word. ${ }^{69}$ Indien daar wel probleme met ' $n$ kliënt sou ontstaan, kan die hulp van die gereg ook ingewin word. ${ }^{70}$

\section{Die gebrek aan beheer oor die verspreiding van MIV}

Dit is 'n onbetwiste feit dat MIV 'n groot bron van kommer nie, net in SuidAfrika nie, maar ook in die res van die wêreld is. Die impak van die VIGSepidemie op vrouens is veral dramaties omrede heteroseksuele oordrag as die grootste bron (tot $71 \%$ ) van MIV-oordrag beskou word. ${ }^{71}$ Daar is dus geen twyfel oor die moontlikheid van die MIV-infektering van sekswerkers deur middel van hul kliënte of omgekeerd in die uitoefening van hulle daaglikse werksaamhede nie. Die erns van die oordrag van MIV aan sekswerkers se kliënte is daarin geleë dat die virus weer deur hierdie kliënte aan hulle vrouens, ander seksmaats en uiteindelik hul pasgebore kinders oorgedra kan word. ${ }^{72}$

66 "Violence and Legalized Brothel Prostitution in Nevada. Examining Safety, Risk, and Prostitution Policy" 2005 20(3) J of Interpersonal Violence 271.

67 Brents en Hausbeck 2005 20(3) J of Interpersonal Violence 275: "Nevada's statewide prostitution policies are remarkably sparse considering Nevada is so well known for its legalized bordellos. The Nevada Revised Statutes have only two sections related to prostitution. The first is the section that in effect legalizes prostitution; the law does so by prohibiting prostitution in Nevada counties with populations of over 400000 . This law leaves open the possibility for legal prostitution in Nevada counties with populations below this limit. The second section of Nevada's law on prostitution regulates pandering, pimping, zoning, advertising and sexually transmitted diseases." 2005 20(3) J of Interpersonal Violence 280.

69 Brents en Hausbeck 2005 20(3) J of Interpersonal Violence 281.

70 Ibid.

71 "A Virus Out of Control" 1992-07-03 The Times Higher. Kyk ook Varga "Coping with HIV/AIDS in Durban's Commercial Sex Industry" 2001 13(3) AIDS CARE 352: "The majority of infections are heterosexual and among young adults." Kyk verder Slonim-Nevo, Mukuka en Tembo "AIDS-related Knowledge, Attitudes and Behaviour Among Urban Youths in Zambia" 2001 44(4) International Social Work 487: "Aids in sub-Saharan Africa is primarily a heterosexual problem." Asook Dane "The Voices of Thai Women Living with HIV/AIDS" 2002 International Social Work 45(2):185. "Among heterosexual men, unprotected sex with female commercial sex workers is the primary factor contributing to HIV transmission."

72 Prybylski en Alto "Knowledge, Attitudes, and Practices Concerning HIV/AIDS Among Sex Workers in Phnom Penh, Cambodia" 1999 11(4) AIDS CARE 460. Kyk ook Ruxrungtham, Brown en Phanuphak "HIV/AIDS in Asia" 2004(364) The Lancet 69: "In most places HIV spreads first among injecting drug users, followed by HIV spread among sex workers. Clients of sex workers are the next link in the chain and they then transmit the virus to their female sexual partners. Most women infected in Asia have been the monogamous wives or regular partners of higher risk men. HIV in children, through maternal infection, represents the final link in the chain." 
Volgens Peltzer et $a l^{73}$ het 'n opname in 1996 onder 145 vroulike sekswerkers by vragmotor-oornagstaanplekke in die Natalse middellande, daarop gedui dat $50,3 \%$ van die sekswerkers MIV-positief was. Wat vragmotor-oornagstaanplekke langs die Tanzanië-Zambiese hoofweg betref was die voorkoms van MIV en sifilis onder vroue, $50 \%$ en $24 \%$ onderskeidelik. ${ }^{74}$ In Johannesburg het ' $n$ opname deur Rees et al ${ }^{75}$ in die jaar 2000 getoon dat $45 \%$ van die sekswerkers MIV-positief was. $\mathrm{Na}$ aanleiding van 'n studie deur Legget ${ }^{76}$ in 2001 onder 249 sekswerkers in drie van Suid-Afrika se grootste stede, is bevind dat $66 \%$ van die nie-blanke sekswerkers MIV-positief was in vergelyking met $18 \%$ blanke en $17 \%$ gekleurde sekswerkers. Verskeie studies oor die afgelope agt jaar het daarop gedui dat ongeveer $50 \%$ van al die vroulike sekswerkers in Ghana en Suid-Afrika MIV-positief is. ${ }^{77}$

Die twee hoofredes vir die hoë voorkoms van MIV onder sekswerkers blyk uit die aantal seksmaats (kliënte) ${ }^{78}$ aan wie diens gelewer word, asook en veral die swak gebruik van kondome in die uitoefening van sekswerkers se beroep. $^{79}$

Met die volharding van die voorkomingsbenadering beskik Suid-Afrika tans oor geen beheer en kontrole wat betref die verspreiding van MIV deur sekswerkers na hulle kliënte en omgekeerd nie.

73 "Characteristics of Female Sex Workers and their HIV/AIDS/STI Knowledge, Attitudes and Behaviour in Semi-urban Areas in South Africa" 2004 27(1) (Denosa) Curationis 4.

74 Outwater et al "Health care seeking behaviour for sexually transmitted diseases among commercial sex workers in Morogoro, Tanzania" 2001 3(1) Culture, Health \& Sexuality 20.

75 "Commercial sex workers in Johannesburg: Risk behaviour and HIV status" 2000 (96) South African $J$ of Science 284.

76 "Drugs, sex work, and HIV in three South African cities" 2001 32(1) Society in Transition 103.

77 UNAIDS "Report on the Global Aids Epidemic" 2006107.

78 Peltzer et al 2004 27(1) (Denosa) Curationis 6. In sy studie onder 70 sekswerkers (29 van Phalaborwa en 41 van die Tzaneen-omgewing), was die gemiddelde getal verskillende seksmaats/kliënte per sekswerker ongeveer 4.1 per week met ' $n$ gemiddeld van 2.4 kliënte aan wie hulle diens op hulle laaste werksdag gelewer het. Kyk ook Rees et al 2000 (96) South African J of Science 283. Die meeste sekswerkers, $88 \%$ in die jaar 2000 in Johannesburg, het ongeveer 5 kliënte daagliks gehad. Kyk verder Varga 2001 13(3) AIDS CARE 355. Die gemiddelde getal daaglikse kliënte van sekswerkers in die jaar 2001 in Durban was net onder drie. In 'n studie deur Karim et al "Reducing the risk of HIV infection among South African sex workers: Socio-economic and gender barriers" 1995 85(11) American Journal of Public Health 1522, onder twaalf sekswerkers by vragmotoroornagstaanplekke tussen Durban en Johannesburg, het die sekswerkers aangedui dat hulle in totaal aan ongeveer 266 kliënte per week diens lewer.

79 Kyk Peltzer et al 2004 27(1) (Denosa) Curationis 6. Tien van die sewentig sekswerkers in Peltzer se studie onder sekswerkers in Suid-Afrika het nie van kondome gebruik gemaak tydens gemeenskap met hul laaste kliënte van wie hul betaling ontvang het nie. Kyk ook Varga en Blose "The symbolism and dynamics of condom use among commercial sex workers in Durban, South Africa" 1996 3(2) African Anthropology 90. In hulle studie is bevind dat slegs $22 \%$ van die sekswerkers in Durban altyd kondome gebruik, terwyl $78 \%$ gewoonlik van kondome gebruik maak. Kyk verder Karim et al 1995 85(11) American J of Public Health 1522. Volgens hulle studie is bevind dat sewe uit die twaalf sekswerkers wat by vragmotor-oornagstaanplekke tussen Durban en Johannesburg diens gelewer het, van geen voorbehoedmiddel gebruik gemaak het nie. 
Thailand, Australië en Nevada, in die Verenigde State van Amerika, is voorbeelde van lande wat reeds sukses bereik het in die voorkoming van MIV-verspreiding deur sekswerkers. Hierdie onderskeie lande geniet kortliks aandag.

\section{Thailand}

Die Entertainment Places Act van 1966, wat vandag steeds van krag is, maak voorsiening vir die lewering van "spesiale dienste" deur vroue in Thailand. ${ }^{80}$

Met verwysing na die groot rol wat sekswerkers in die verspreiding van MIV in Thailand gespeel het, het die nasionale leiers van die land vinnig gereageer ten einde voorkomingsmaatreëls meer doeltreffend te maak. ${ }^{81}$ Die konsep van 100\%-verpligte gebruik van kondome het in 1991 in Thailand ontstaan, waarvolgens die regering 'n beleid ontwerp het wat die gebruik van kondome in alle bordele verplig het. Bordeeleienaars wat nie daaraan gehoor gegee het nie, was onderworpe aan sanksies en herhaaldelike nie-nakoming kon daartoe lei dat die betrokke bordeel gesluit moes word. ${ }^{82}$ Die resultate van die beleid was indrukwekkend met 'n groei in die gebruik van kondome (deur sekswerkers wat aan die studie deelgeneem het) vanaf $14 \%$ tot $90 \%$. 'n Verdere aanduiding van sukses was 'n $79 \%$ afname in seksueel-oordraagbare siektes opgedoen deur manspersone wat gereeld bordele besoek het. ${ }^{83}$

\section{Australië}

Prostitusie word deur verskeie wette ${ }^{84}$ in sommige dele van Australië gereguleer. $^{85}$

Australië, wat van die laagste MIV-syfers in die wêreld het, beweer dat die rede daarvoor is dat hulle sekswerkers kon bereik en oplei en nie net op die gebruik van kondome en veilige seks klem gelê het nie, maar sekswerkers ook bemagtig het om beter oor hulleself as sekswerkers te voel. ${ }^{86}$ In

80 Wikipedia Encyclopedia "Prostitution in Thailand" http://en.wikipedia.org/wiki/Prostitution in_Thailand (nageslaan 26 Februarie 2008): "The Entertainment Places Act of 1966, still in effect today, makes it possible for Thais to render 'special services'. This is done, for example, by establishing such places as massage parlours where men can come and look at women, who are sitting separated by a glass wall, and may choose whom they want. The women go to a room where they bathe and massage the customers, but in reality may do much more than that. This Act was designed to pave the way for brothels to be legalized under the guise of massage parlours, bars, night-clubs and tea-houses".

81 Ruxrungtham et al 2004(364) The Lancet 76.

82 Dadian "Can Solidarity and Government Policy Reduce HIV Risk in Sex Work?" 2002 Horizons Report 1.

83 Dadian 2002 Horizons Report 2.

84 Victoria - Die Prostitution Control Act van 1994; Queensland - Die Prostitution Act van 1999; en Nieu-Suid Wallis - Disorderly Houses Act van 1943 soos gewysig.

85 Murray "Labour Regulation in the Legal Sex Industry" 2003(16) Australian Journal of Labour Law 2-3.

86 mAy-welby "The Importance of Facing HIV/AIDS with Scrupulous Honesty" 2004 5(1) InterAsia Cultural Studies 150. 
Australië befonds die regering seksuele-gesondheidklinieke, wat gratis is, geen identiteit verlang nie en waar vertroulikheid gewaarborg word. Hierdie klinieke kan dus besoek word sonder die vrees dat iemand anders van jou status as sekswerker bewus sal word. Terselfdertyd bied dit die nodige gesondheidsorg, ondersoeke en gesondheidsvoorligting aan dié wat 'n behoefte daaraan het. ${ }^{87}$ Projekte word ook deur die federale en staatsregering befonds sodat sekswerkers besoek kan word, onderrig kan ontvang en aangemoedig word om bogenoemde klinieke te besoek. Daar word van sekswerkers self gebruik gemaak om ander sekswerkers te bereik en te onderrig, want volgens mAy-welby ${ }^{88}$ luister alle professionele persone baie makliker na hulle kollegas as na 'n persoon wat nog nooit soortgelyke werk verrig het nie. Die sukses van so 'n praktiese benadering spreek duidelik uit die feit dat MIV onder sekswerkers in Australië minder as $1 \%$ is en dit minder is as die algemene voorkoms van MIV onder die res van die algehele bevolking. ${ }^{89}$

\section{Nevada}

Prostitusie in bordele is hier ook wettig. ${ }^{90}$

In Nevada moet elke persoon wat aansoek doen as 'n sekswerker 'n MIVbloedtoets ondergaan. ${ }^{91}$ Die toetsuitslag moet negatief wees voordat 'n sekswerker as gelisensieerd beskou word ten einde diens as sekswerker te mag verrig. Hierna volg verpligte weeklikse toetse vir seksueel-oordraagbare siektes, terwyl MIV-toetse op 'n maandelikse basis plaasvind. Indien 'n sekswerker positief sou toets vir 'n seksueel-oordraagbare siekte word sy belet om sekswerk te verrig alvorens die nodige behandeling ondergaan is en haar "health card" weer uitgereik is. Indien sy egter MIV-positief sou toets, kan sy nie haar werk as sekswerker by ' $n$ bordeel voortsit nie. Die straf vir nie-nakoming hiervan wissel tussen 2-10 jaar-gevangenisstraf of 'n boete van $\$ 10000 .^{92}$ Die gebruik van kondome is verpligtend. ${ }^{93}$ Sekswerkers word verder opgelei in die visuele inspeksie van seksueel-oordraagbare siektes by kliënte. Indien tekens van laasgenoemde wel aanwesig is, word die kliënt se geld terugbetaal en word hy versoek om die perseel te verlaat. ${ }^{94}$ Die resultaat van bogenoemde was dat geen geregistreerde sekswerker in

\footnotetext{
mAy-welby 2004 5(1) Inter-Asia Cultural Studies 151.

Ibid.

Ibid.

90 Brents en Hausbeck 2005 20(3) J of Interpersonal Violence 275: "Nevada's statewide prostitution policies are remarkably sparse considering Nevada is so well known for its legalized bordellos. The Nevada Revised Statutes have only two sections related to prostitution. The first is the section that in effect legalizes prostitution; the law does so by prohibiting prostitution in Nevada counties with populations of over 400000 . This law leaves open the possibility for legal prostitution in Nevada counties with populations below this limit. The second section of Nevada's law on prostitution regulates pandering, pimping, zoning, advertising and sexually transmitted diseases."

91 Ingevolge die Nevada Administrative Code 441A.800.

92 Brents en Hausbeck 2005 20(3) J of Interpersonal Violence 276.

93 Ingevolge die Nevada Administrative Code 441A.805. Kyk ook Brents en Hausbeck 2005 20(3) J of Interpersonal Violence 286.

94 Brents en Hausbeck 2005 20(3) J of Interpersonal Violence 286.
} 
Nevada vanaf 1986 MIV-positief getoets het nie. ${ }^{95}$ Hierdie rekord kan nie deur die algehele populasie bereik word nie en dit maak in werklikheid uit ' $n$ gesondheidsoogpunt seksuele omgang met 'n sekswerker van Nevada in sommige gevalle veiliger as seksuele omgang in die huwelik. ${ }^{96}$

\section{Sekswerkers se gebrek aan arbeidsregte}

Volgens Petzer ${ }^{97}$ spog Suid-Afrika graag met sy menseregte-kultuur, maar is selfs die mees basiese menseregte en arbeidsregte sekswerkers nie beskore nie. $^{98}$

Alhoewel selfs die Internasionale Arbeidsorganisasie ${ }^{99}$ regerings tans aanmoedig om die seksbedryf te wettig en sodoende die seksindustrie te belas en as wettige beroep te reguleer, ${ }^{100}$ geniet sekswerkers in Suid-Afrika steeds geen arbeidsregte nie, vanweë die onwettige aard van die beroep. ${ }^{101}$

Die Kommissie vir Konsiliasie, Mediasie en Arbitrasie (KKMA) het onlangs in die saak van "Kylie" $v$ Van Zyl t/a Brigettes ${ }^{102}$ bepaal dat 'n sekswerker (vanweë die onwettige aard van die beroep) nie as "werknemer" vir die doeleindes van die Wet op Arbeidsverhoudinge ${ }^{103}$ kwalifiseer nie en die KKMA gevolglik nie jurisdiksie het om haar saak van onbillike ontslag te oorweeg nie. ${ }^{104}$ Kylie is op grond van beweerde dwelmmisbruik en

95 Wikipedia Encyclopedia "Prositution in Nevada" http://en.wikipedia.org/wiki/Prostitution in_Nevada (nageslaan op 26 Februarie 2008).

96 Leggett "The Least Formal Sector: Women in Sex Work" 1998(13) Crime and Conflict 2124.

97 "Seks is Arbeid, sê Shane" 2002-03-08 Die Burger.

98 Kyk ook Hernández-Truyol en Larson "Sexual Labor and Human Rights" 2006(37) Columbia Human Rights LR 395: "That labor is an indivisible part of the fabric of fundamental human rights is already a political and legal fact; yet the implications of this fusion have been little explored in the debate over sexual labor."

99 Kyk ook International Labour Organization (ILO) "About the ILO: Mandate" http://www.ilo.org/ public/english/about/index.htm (nageslaan op 8 September 2006): "The International Labour Organization is the UN specialized agency which seeks the promotion of social justice and internationally recognized human and labour rights."

100 Raymond "Legitimating Prostitution as Sex Work: UN International Labour Organization Calls for Recognition of the Sex Industry" http://sisyphe.org/article.php3?id_article=689 (nageslaan op 15 Maart 2006). Kyk ook Bruch "Models Wanted: The Search for an Effective Response to Human Trafficking" 2004 40(1) Stanford J of International Law 25: "The ILO has also taken a significant step towards acknowledging sex work as an international labor issue. Although it does not take a position on the legal status of prostitution, it has acknowledged that, at least in South-East Asia, the sex business has assumed the dimensions of a commercial sector, one that contributes substantially to employment and national income in the region. This report is groundbreaking for moving the discussion of prostitution and other sex work into the labor framework." Kyk verder Inglis 2001(7) Buffalo Human Rights LR 84: "The ILO report continues to propose that policy concerns for women who choose sex work should focus on improving their working conditions and social protection so as to ensure that they are entitled to the same labor rights and benefits as other workers."

101 Kyk ook "Indoor Sex Workers out in the Cold" 2001-08-09 Weekly Mail \& Guardian: "It goes without saying that because sex work is illegal, labour laws do not currently apply to these workers."

102200728 ILJ 470 (CCMA).

10366 van 1995.

104 Bosch en Christie "Are Sex Workers ‘Employees'?" 2007(28) ILJ 804. 
wangedrag ${ }^{105}$ ontslaan en het voor ontslag geen verhoor of geleentheid gehad om haarself te verdedig laat uit nie. ${ }^{106}$ Die Kommissaris het op die volgende oorwegings gewys ter stawing van sy bevinding dat die saak nie deur die KKMA aangehoor kon word nie: ${ }^{107}$

- Daar kan nie praktiese uitvoering aan 'n bevel van heraanstelling gegee word nie.

- Die uitbreiding van die Wet op Arbeidsverhoudinge ${ }^{108}$ ten einde die werksaamhede van sekswerkers in te sluit kan tot absurde gevolge aanleiding gee. Die sekswerker se weiering om 'n bevel van die werkgewer te gehoorsaam sal tog telkemale neerkom op die weiering om aan ' $n$ onwettige bevel gehoor te gee.

- Alhoewel prostitusie openlik bedryf word, die KKMA verplig is om strafregtelike bepalings te eerbiedig.

Die saak is intussen na die Arbeidshof in Kaapstad vir hersiening verwys en die uitspraak was nog onbekend op die stadium van die skryf van hierdie artikel. $^{109}$

Hoe dit ook al sy, die dekriminalisering van die seksbedryf sal 'n besliste verbetering ten aansien van sekswerkers se toegang tot arbeidsregte tot gevolg hê. Hierdie toegewing is noodsaaklik om sekswerkers teen uitbuiting, onbillike en onveilige werksomstandighede te beskerm. Dit sal verder verseker dat daar teen uitbuitende bordeeleienaars opgetree kan word sonder dat bordele totaal en al verbied word.

Weinig lande volg egter tans 'n volkome arbeidsbenadering (sonder 'n mate van regulering) soos in paragraaf 54 hierbo verduidelik. Australië, Nederland en Nieu-Seeland is wel voorbeelde van lande waar sekswerkers reeds oor arbeidsregte beskik. Hierdie lande geniet dus kortliks aandag.

\section{Australië}

Soos reeds genome, word prostitusie deur verskeie wette ${ }^{110}$ in sommige dele van Australië gereguleer. ${ }^{11}$

Die hoofmeganisme wat gebruik word om prostitusie in Victoria te reguleer is die Prostitution Control Act van $1994 .{ }^{112}$ Regulasies is te vinde in hierdie wetgewing asook die Health Act van 1958 oor hoe seksdienste in

105 Ibid.

106 Legalbrief TODAY "Labour: Precedent-setting Case to be Heard Today" http://www.legal brief.co.za (nageslaan op 7 Februarie 2008).

107 Bosch en Christie 2007(28) ILJ 804-805.

10866 van 1995.

109 Legalbrief TODAY "Labour: Sex Worker Judgment Reserved" http://www.legalbrief.co.za (nageslaan op 8 Februarie 2008).

110 Victoria - Die Prostitution Control Act van 1994; Queensland - Die Prostitution Act van 1999; en Nieu-Suid Wallis - Disorderly Houses Act van 1943 soos gewysig.

111 Murray 2003(16) Australian J of Labour Law 2-3.

112 Murray 2003(16) Australian J of Labour Law 7. 
Victoria verskaf moet word. ${ }^{113}$ Een van die maniere waarmee die Prostitution Control Act van 1994 poog om prostitusie in Victoria te beheer is die skepping van 'n gelisensieerde sisteem vir bedrywers van seksuele dienste, asook vir mense wat hierdie dienste bestuur indien die verskaffer nie op die perseel teenwoordig is nie. Lisensiëring vind plaas deur die Business Licensing Authority wat onder andere daarna kyk of die aansoeker die nodige maatreëls wat die veiligheid van persone werksaam in die onderneming verseker, getref het. ${ }^{14}$ Die regulering van wettige sekswerk ingevolge die Wet, word gekomplementeer deur 'n uitgebreide stel regulasies soos vervat in die Prostitution Control Regulations van 1995, en die Health (Infectious Disease) Regulations van 2001 soos daargestel deur die Health Act. Regulasie 19 van die Prostitution Control Regulations spesifiseer veiligheidsvereistes wat nagekom moet word deur gelisensieerde operateurs van sekswerk. Dit sluit onder andere die verbod op 'n gelisensieerde operateur se reg om 'n sekswerker se besluit om nie 'n seksuele diens aan 'n kliënt te veskaf nie omrede dit gewelddadig of onveilig is, in. ${ }^{115}$

In Nieu-Suid Wallis het die staat se veiligheidskommissie onlangs hulle Gesondheids- en Veiligheidsriglyne ${ }^{116}$ vir bordele uitgereik wat 'n verskeidenheid potensiële risiko's vir die wêreld se oudste beroep behels, insluitende glibberige stortvloere en waggelende bedrame. Ingevolge die riglyne beveel die staat bordeeleienaars om van helder ligte gebruik te maak vir die inspektering van kliënte vir seksueel oordraagbare siektes en ook van skoon "boei-hou- en disiplinering" -toerusting wat nie te swaar is nie. Dit waarsku ook teen die "Occupation Overuse Syndrome", wat vir sekswerkers uit rug en gewrigpyne bestaan as gevolg van swak matrasse, massering en herhalende bewegings. ${ }^{117}$ Die Nieu-Suid Wallis-regering wil verder ook verseker dat sekswerkers voldoende opleiding oor veilige seksgewoontes, koffietye en vakansieverlof kry en herinner bordeeleienaars aan hulle regsplig om 'n rookvrye omgewing aan werknemers te bied. ${ }^{118}$

\section{Nederland}

In die jaar 2000 is die bordeelverbod van 1911 in Nederland ingevolge die Wet Opheffing Bordeelverbod van 2000, opgehef. ${ }^{119}$

Sekswerkers is tans geregtig op maatskaplike versekering en vorm unies. Werkgewers van sekswerkers moet ingevolge bestaande arbeidsregte optree, by gesondheids- en veiligheidsregulasies hou en maatskaplike versekering en belasting betaal. Sekswerkers self is ook belasting-

113 Murray 2003(16) Australian J of Labour Law 7-8.

114 Murray 2003(16) Australian J of Labour Law 12-13.

115 Ibid.

116 WorkCover NSW "Health and Safety Guidelines for Brothels" Guide 2001 WorkCover NSW Health and Safety Guide.

117 Media Correspondent "Hey Kids, Play Safe" 2002-03-04 The Report.

118 Ibid

119 Amsterdam Historisch Museum "Liefde te Koop - Teksten" www.ahm.nl/teksten.php?id= 4\&PHPSESSID=b53a2710521802c1aa83155c5c66ef97 (nageslaan op 15 Maart 2006). 
pligtiges. ${ }^{120}$ Bordele word in sekere areas toegelaat en moet aan plaaslike regulasies voldoen. In 2002 het die meeste munisipaliteite van Nederland reeds 'n lisensiëringstelsel vir bordele opgestel ingevolge waarvan wettige werknemers- en veiligheidsmaatreëls vereis word. ${ }^{12}$

\section{Nieu-Seeland}

Sekswerk is ingevolge die Prostitution Reform Act van 2003 gedekriminaliseer.

Die doel van die Prostitution Reform $A c t^{122}$ is hoofsaaklik om 'n raamwerk te skep wat die menseregte van sekswerkers verseker en hulle teen uitbuiting beskerm. Hierdie Wet bevat afdelings wat onder andere oor ouderdoms-beperkings van sekswerkers, bordeelplasing, dwang, kontraktuele verant-woordelikhede, arbeidsregte, bendebetrokkenheid, immigrasiebepalinge, getalle betrokke in sekswerk, beroepsgesondheid- en veiligheid, publieke gesondheid, verantwoordelikheid vir veilige seks, dronkenskap en straatwerk handel.

Reeds een jaar na die inwerkingtreding van die wetgewing het die resultate van Nieu-Seeland se beleid besonder belowend voorgekom. Plaaslike liggame was daartoe in staat om spesiale reëls met betrekking tot sekswerkinrigtings op te stel, soos byvoorbeeld wat betref die afstand vanaf skole en kerke. Sekswerkers in Nieu-Seeland het nou dienskontrakte en hulle arbeidsregte word gehandhaaf. ${ }^{123}$ Ingevolge artikel 17 van die Prostitution Reform $A c t^{124}$ kan 'n sekswerker selfs ten spyte van enige bepaling in haar dienskontrak, weier om 'n seksuele diens te verskaf of om met haar beroep voort te gaan. So 'n weiering sal ook nie haar reg tot vergoeding of ' $n$ voordeel ingevolge die Social Security Act ${ }^{125}$ of die Injury Prevention, Rehabilitation, and Compensation Act, ${ }^{126}$ beïnvloed nie. ${ }^{127}$

\section{GEVOLGTREKKING}

Suid-Afrika kan besluit om die hele kwessie rondom prostitusie onveranderd te laat en met die voorkomingsbenadering volhard. Dit sou egter beteken dat prostitusie met die probleme daaraan verbonde (soos hierbo bespreek) onwettig sal bly voortleef. Sekswerkers sal steeds hul werksaamhede in 'n onbeskermde atmosfeer voortsit waar hul weerloos staan teenoor misbruik en die toediening van geweld, terwyl geen gesondheidskontrole wat hierdie bedryf betref deur die staat toegepas sal kan word nie. Sekswerkers sal

120 Outshoorn "Pragmatism in the Polder: Changing Prostitution Policy in The Netherlands" 2004 12(2) J of Contemporary European Studies 165.

121 lbid

122 Art 3 van Prostitution Reform Act 28 van 2003.

123 Brooks-Gordon "Clients and Commercial Sex: Reflections on Paying the Price: A Consultation Paper on Prostitution" 2005 Criminal LR 433.

12428 van 2003.

125 Social Security Act 1964.

126 Injury Prevention, Rehabilitation, and Compensation Act 2001.

127 Art 18 van Prostitution Reform Act 2003. 
verder gebrandmerk bly as wetsoortreders, wat geen arbeidsregte geniet nie. In die uitoefening van hierdie opsie sal die staat dus bly vasklou aan 'n ou, halfhartige metode om prostitusie die nek in te slaan, wat nog nooit suksesvol was nie.

Die afskaffingsbenadering, met al die nadele daaraan verbonde, soos in paragraaf 52 bespreek, bied ook nie 'n oplossing vir Suid-Afrika nie. Behalwe die nadele daaraan verbonde, is daar 'n goeie kans dat die grondwetlikheid van so 'n benadering in Suid-Afrika geweeg en te lig bevind sal word. Soos reeds genoem, het regters Sachs en O'Regan in hul minderheidsuitspraak in Ellen Jordan en Twee Andere $v$ Die Staat, ${ }^{128}$ daarop gewys dat om die sekswerker as prinsipaal van die misdryf te vervolg, 'n seksuele stereotipe veroorsaak wat op sigself in stryd met geslagsgelykheid is en gevolglik op indirekte diskriminasie neerkom. Hoeveel te meer sal die vervolging van slegs kliënte, terwyl die sekswerker wat haar dienste te koop aangebied het en nou as blote slagoffer van enige vervolging gevrywaar word, nie op onbillike diskriminasie neerkom nie?

In die oorweging van 'n nuwe benadering tot die hantering van prostitusie in Suid-Afrika behoort ' $n$ kombinasie van die regulerings- en arbeidsbenadering dus aandag te geniet. Dit behels die dekriminalisering van prostitusie, gepaardgaande regulering daarvan, asook die erkenning van sekswerk as beroep.

Om prostitusie bloot te dekriminaliseer sonder regulering, wat die versekering van strafmaatreëls ten opsigte van diegene wat buite die vasgestelde riglyne en regulasies optree, bied, mag 'n ongewenste uitwerking hê. Regulering is noodsaaklik om onder andere die oprigting van bordele naby kerke en skole te voorkom en beheer oor die MIV-verspreiding deur en na sekswerkers te verkry deur byvoorbeeld die gebruik van kondome verpligtend te maak. Terselfdertyd kan so 'n kombinasie-model sekswerkers teen geweld beskerm omrede hulle nie meer die gereg hoef te vrees nie en hul reg van billike arbeidspraktyke laat realiseer.

Alhoewel so 'n kombinasie-model al drie kernprobleme voortspruitend uit Suid-Afrika se huidige voorkomingsbenaderings aanspreek en verligting op die onderskeie gebiede mag bring, is dit byna ondenkbaar dat die aanvaarding van 'n nuwe benadering ten opsigte van 'n eeue-oue probleem sonder gebreke sal geskied. In die samelewing van Suid-Afrika waar menseregte so 'n kardinale rol speel, is dit egter die aangewese pad vorentoe. Ontwikkelde lande wat reeds hierdie pad gevolg het en sommige struikelblokke daaraan verbonde oorkom het, behoort vir ons as riglyn te dien.

Die sukses van die voorgestelde kombinasie van 'n regulerings- en arbeidsbenadering sal egter van weldeurdagte regulasies en die effektiewe toepassing daarvan afhang en 'n reuse-uitdaging vir Suid-Afrika as ontwikkelende land bied.

128 Supra 524 par 63. 